\title{
El motín amontonado o el montón amotinado (Tepito-México D.F.)
}

\author{
The crowded riot or the riot in the crowd (Tepito-México D.F.) \\ Enrique Villacís Tapia \\ ISSN (imp): 1390-4825 \\ ISSN (e): 2477-9199 \\ Fecha de recepción: 03/2017 \\ Fecha de aceptación: 05/2017
}

\begin{abstract}
Resumen:
Buscando la voz del lugar, después del vértigo de sumergirme en una ciudad, el D.F. Mexicano, que tiene al Ecuador entero en sí misma, emergí con la acumulación en Tepito, un barrio poco visitado por "visitantes", que encarna mucho esa identidad "amontonada" mexicana, chilanga. Esta es una compilación irresponsable e innecesaria de imágenes, ya que no tiene un fin social ni de denuncia, si no puramente de placer y deleite estético. Sin embargo con una fuerte posición política, esta fotografía no busca ser documental, sin embargo documenta la vida de un lugar, sin mostrar vida en sí mismo, y a partir de su memoria retrata su apretada esencia.
\end{abstract}

Palabras clave: Tepito, d.f. México, estudios visuales, fotografía abstracta, montón, apretado, urbano.

\begin{abstract}
:
After the dizziness of diving in Mexico City, that contains all of Ecuador inhabitants in a much smaller territory, and searching for this place's voice, I surfaced in Tepito. This ia a rarely visited by tourists neighborhood that embodies Mexican and Chilanga identity of "hoarding". This is irresponsible and unnecessary photo compilation, it does not have a social side, but it seeks pure aesthetic pleasure. Nevertheless, and with a strong political stand, this series is not documental, although it documents life in Tepito by not showing life itself, and based on its memory, it exposes its tight existence.
\end{abstract}

Key words: Tepito, d.f. México, visual studies, abstract photography, accumulation, tight, urban.

\begin{abstract}
Autor:
Enrique Villacís Tapia (Quito-Ecuador 1976). Arquitecto (PUCE, 2000), músico, fotógrafo, DJ y artista performático. Becario Fulbright con un Ms. en Administración de Artes (Drexel, Filadelfia 2007). Profesor de Arte y Arquitectura en la Pontificia Universidad Católica (PUCE) (Quito-Actualidad). Líder de Runká banda de electro-rock. Parte de ENSUSITIO, construyendo con lo que hay en su sitio y con su proyecto pedagógico el taller "Con lo que Hay" junto a estudiantes producen proyectos de carácter comunitario poniendo en práctica conocimientos académicos en un contexto real con extensiones en Europa y Latinoamérica. Fotógrafo por la necesidad de entender los entornos más allá del momento.
\end{abstract}




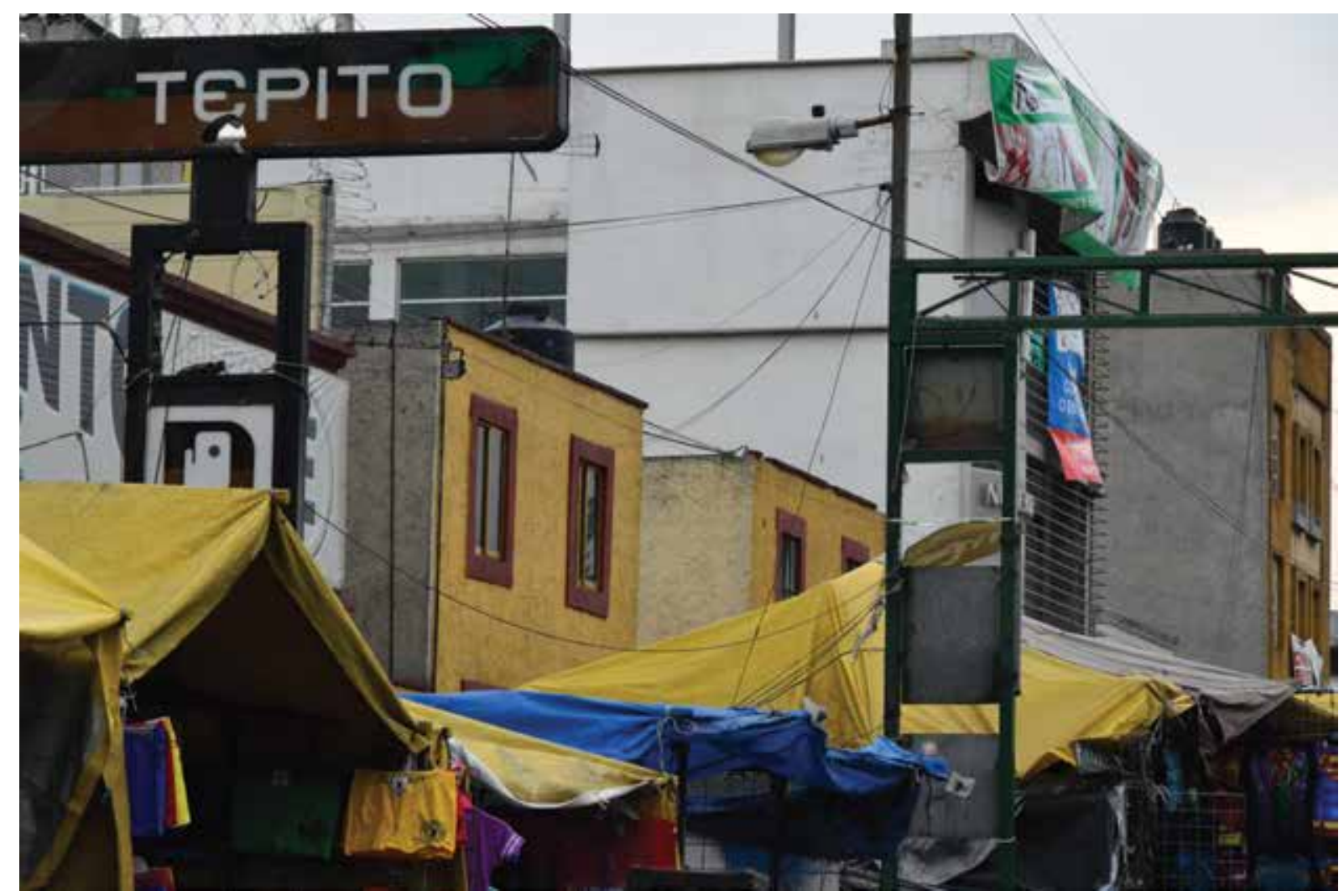




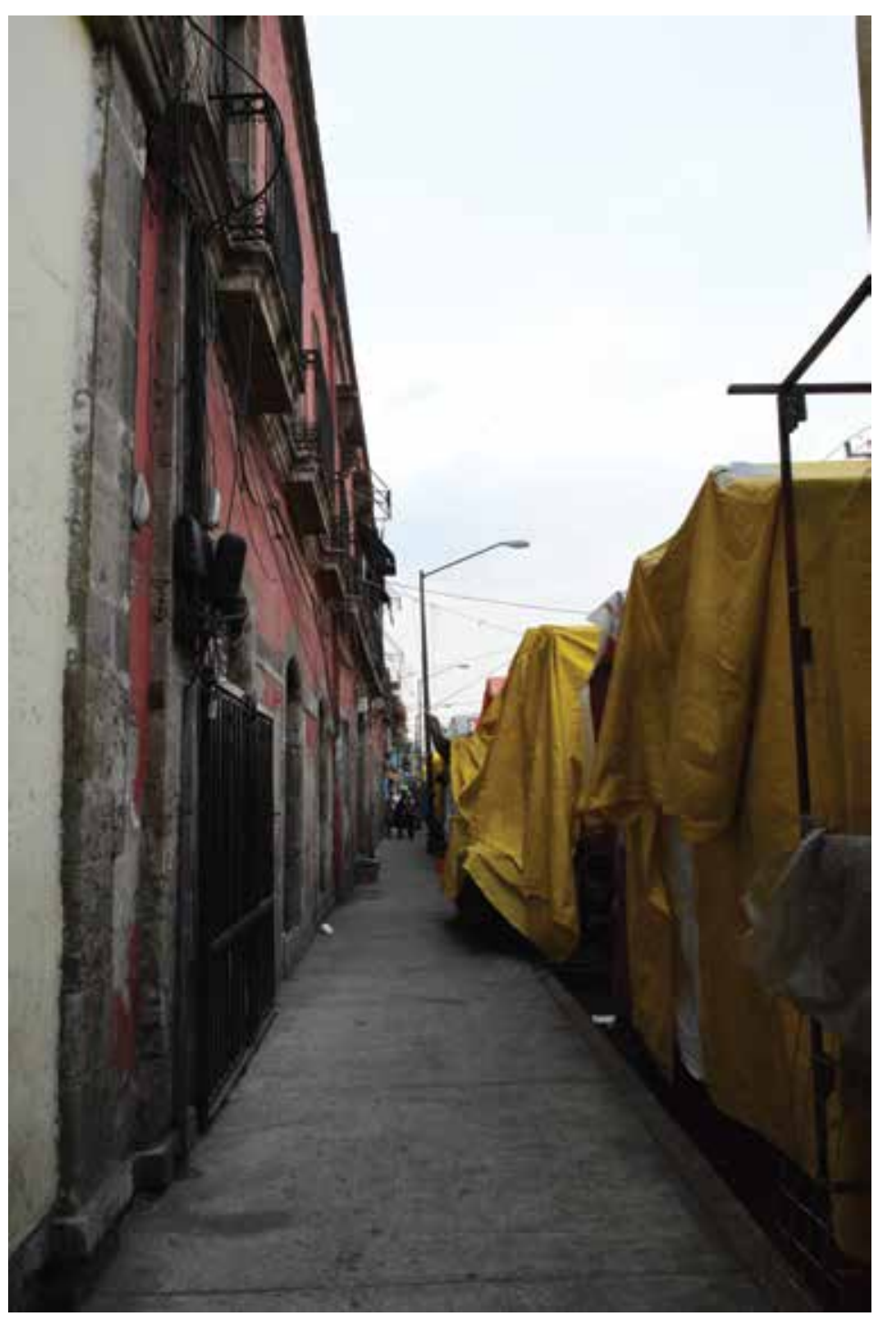




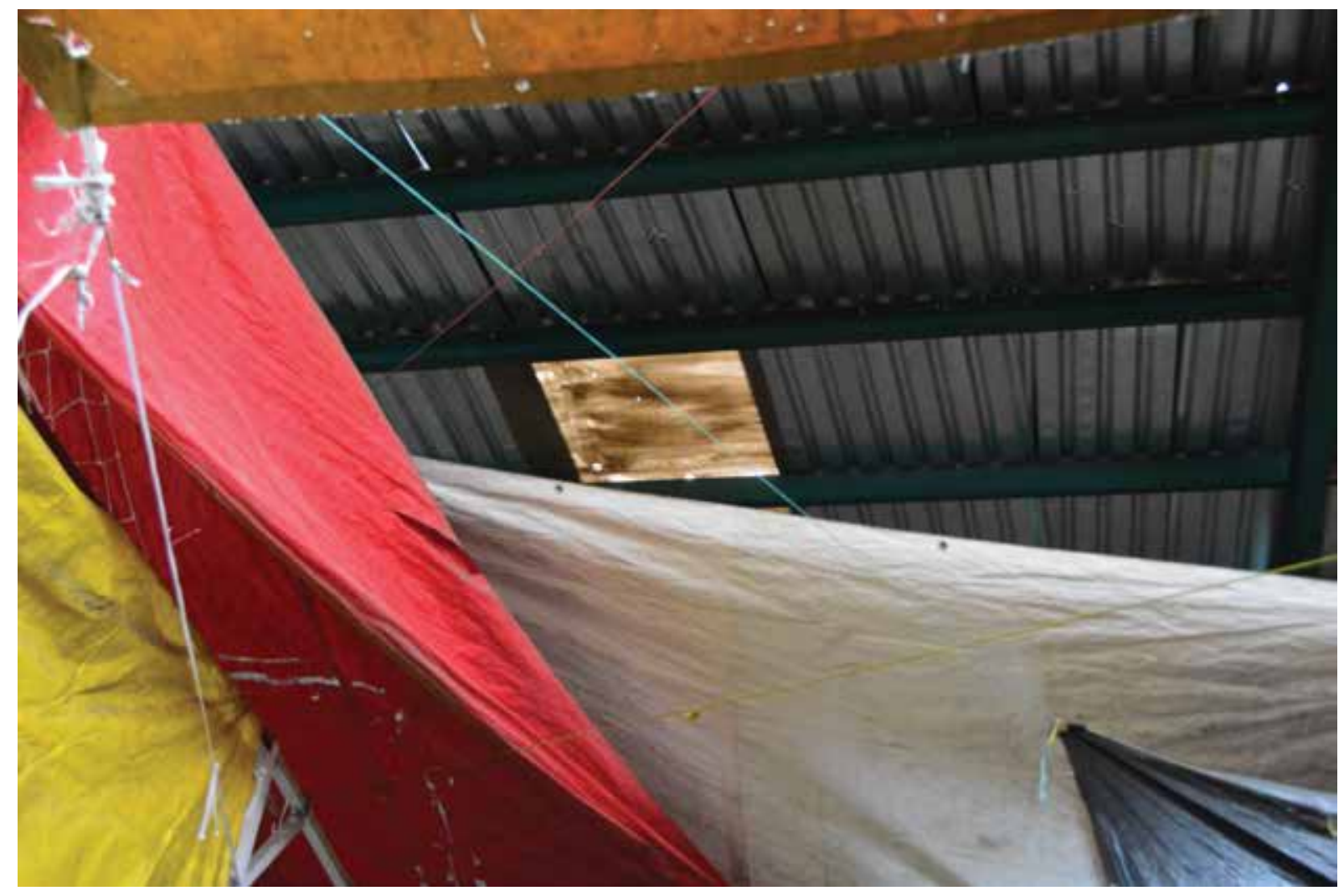




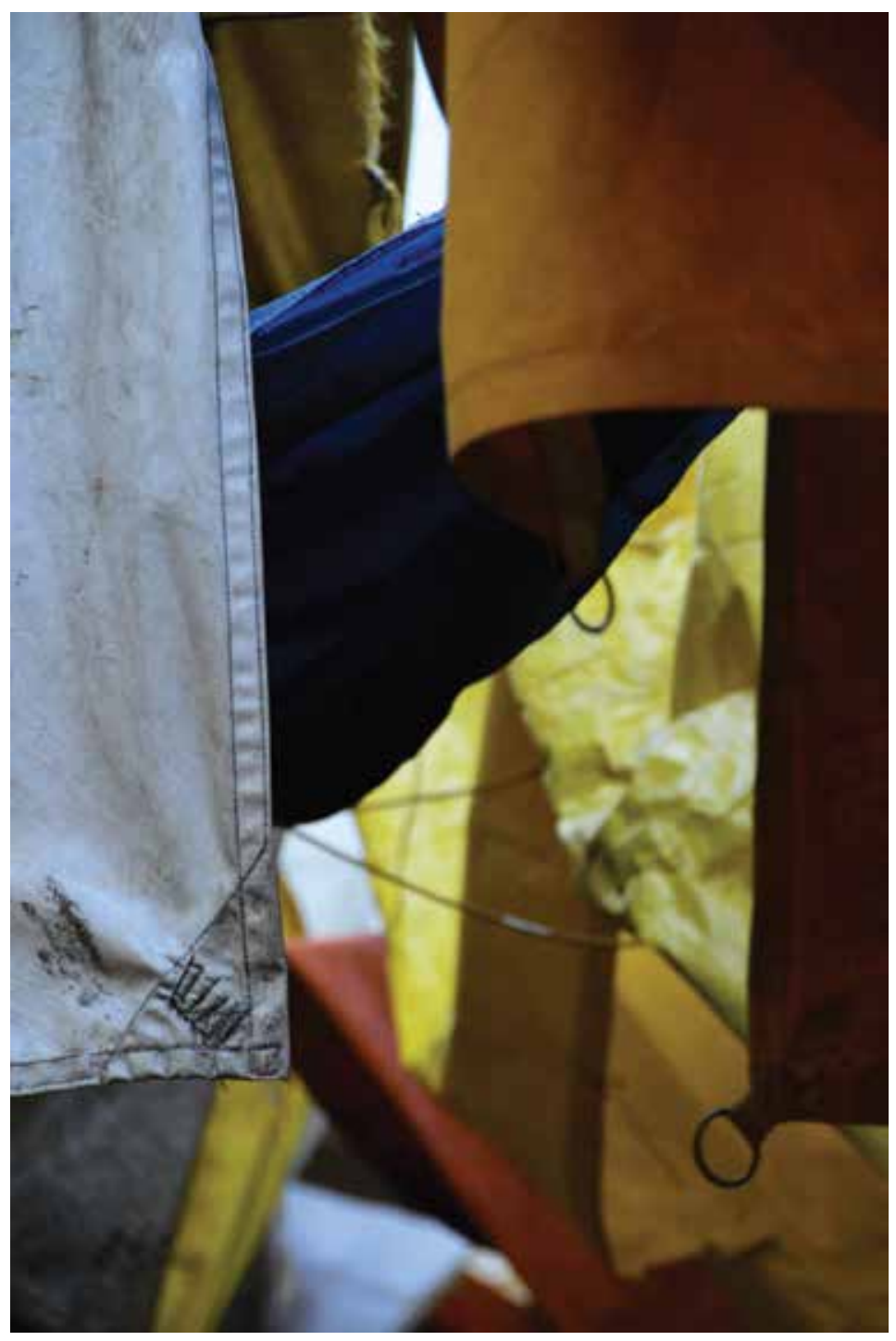




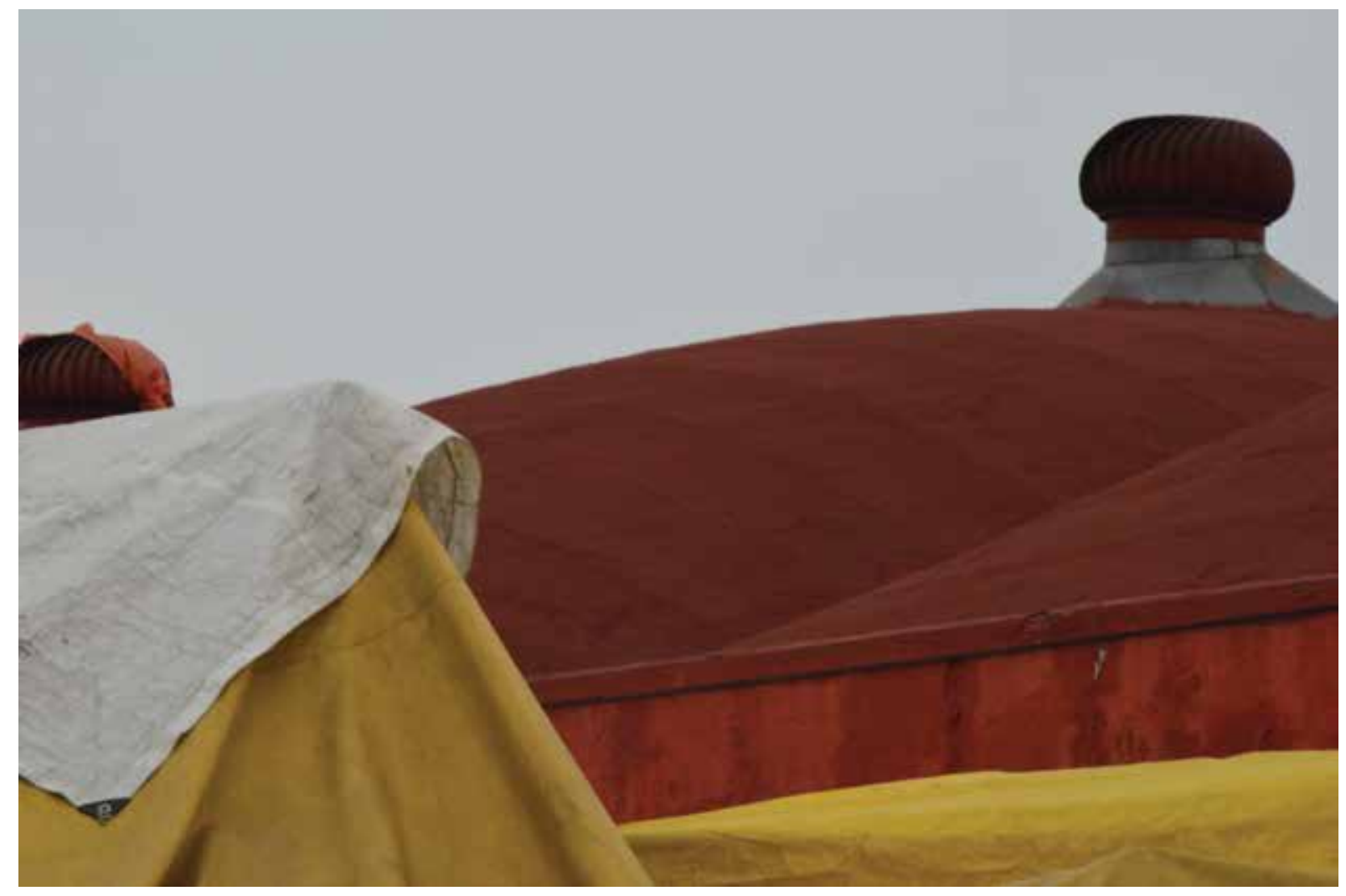




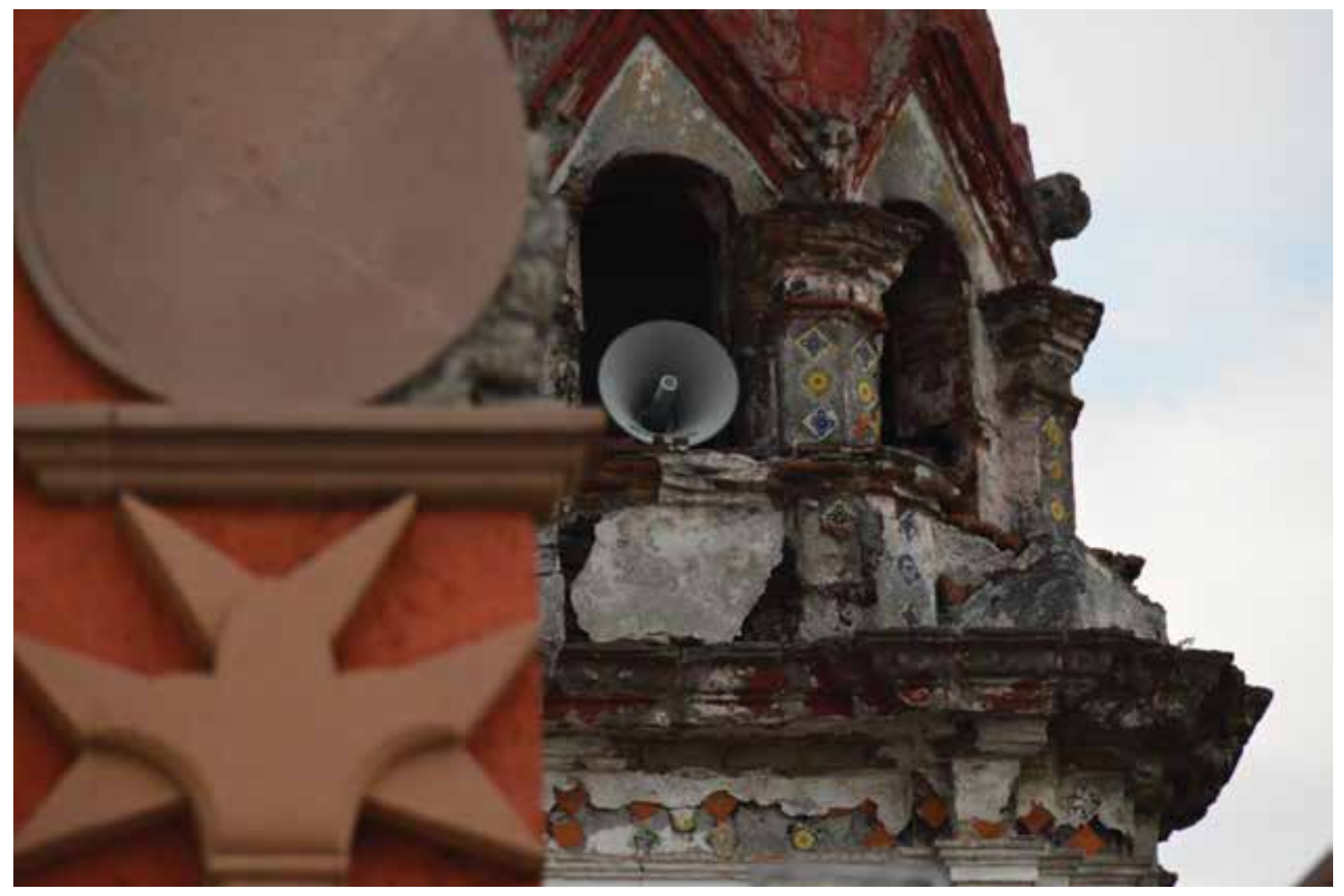




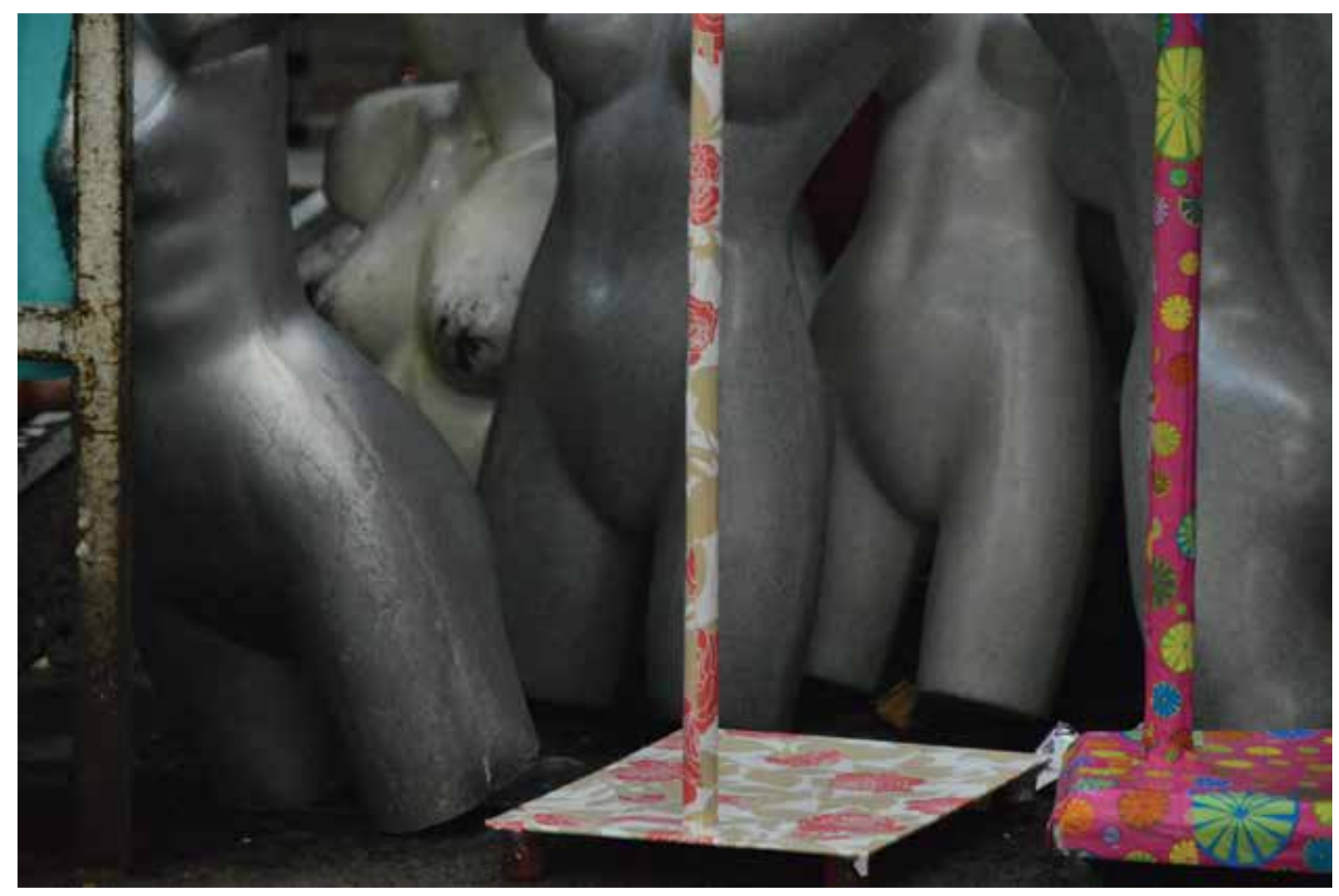




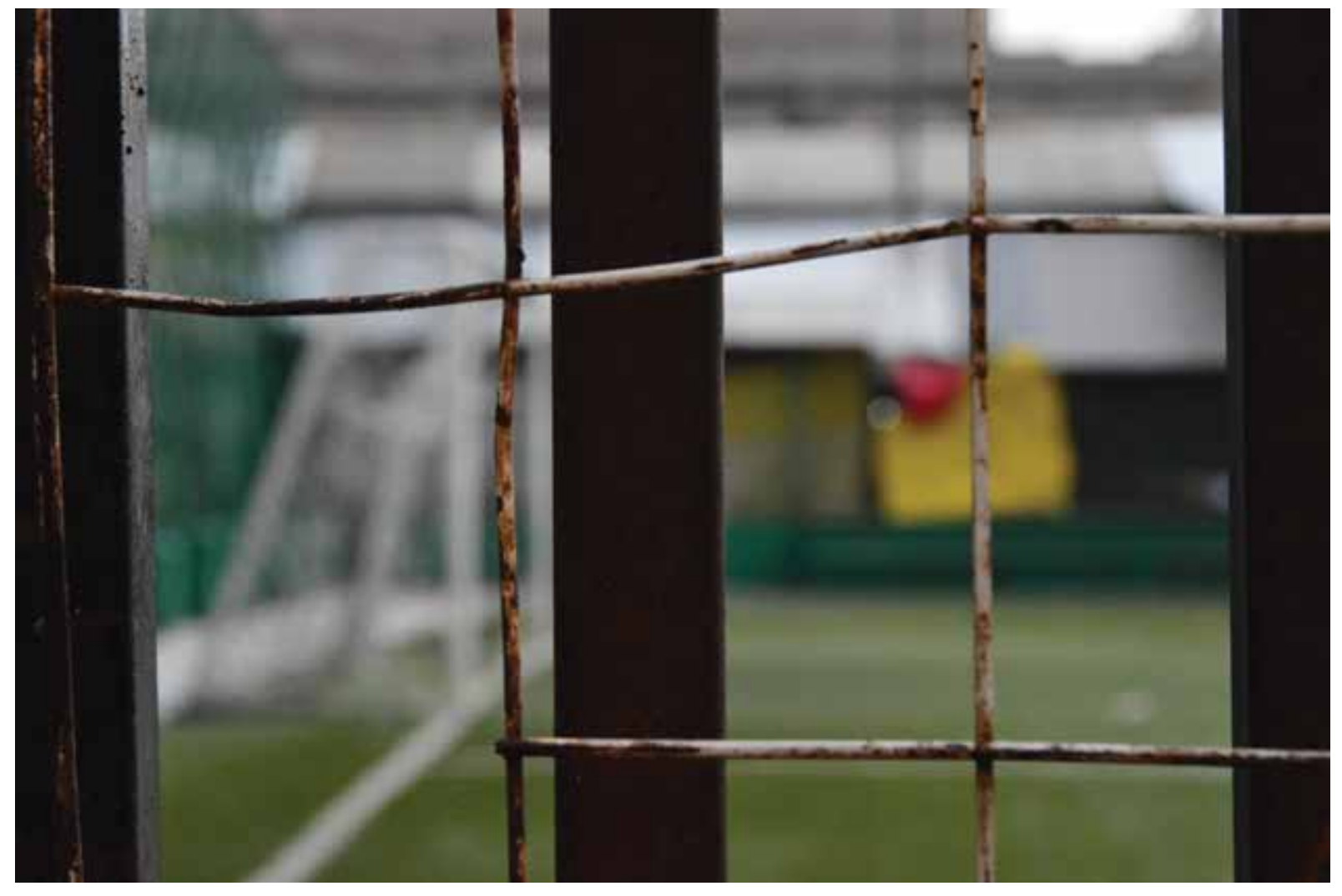



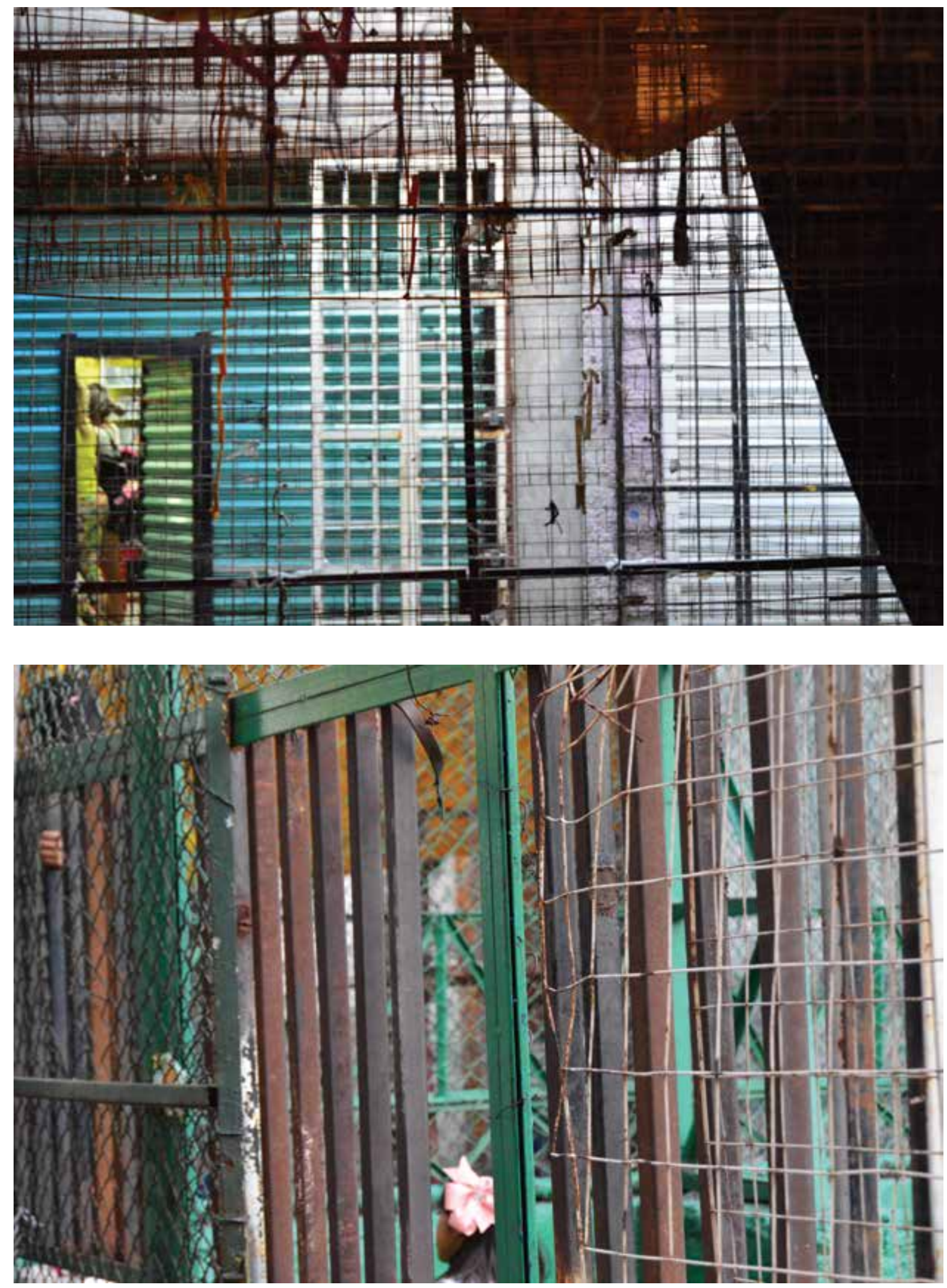


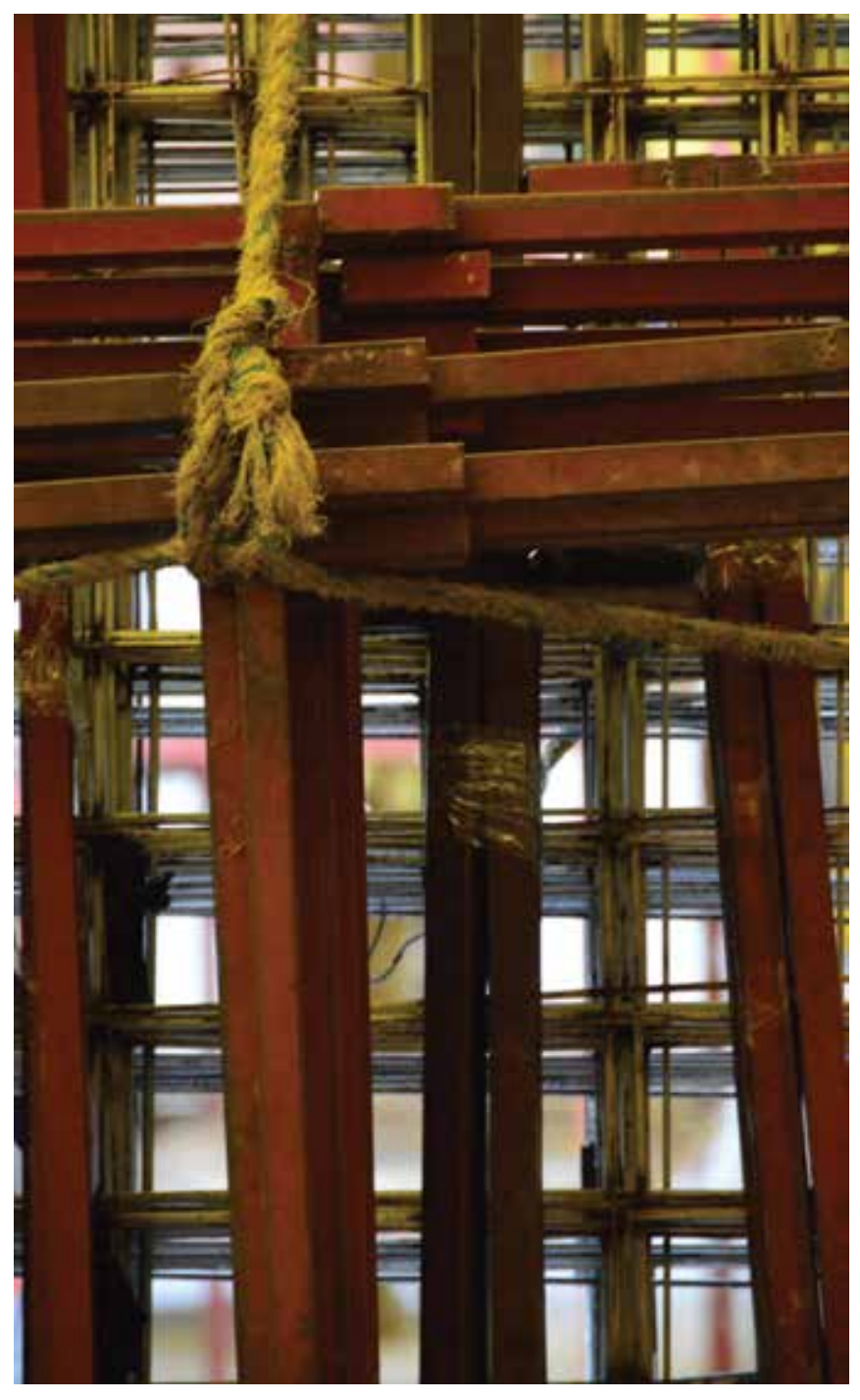




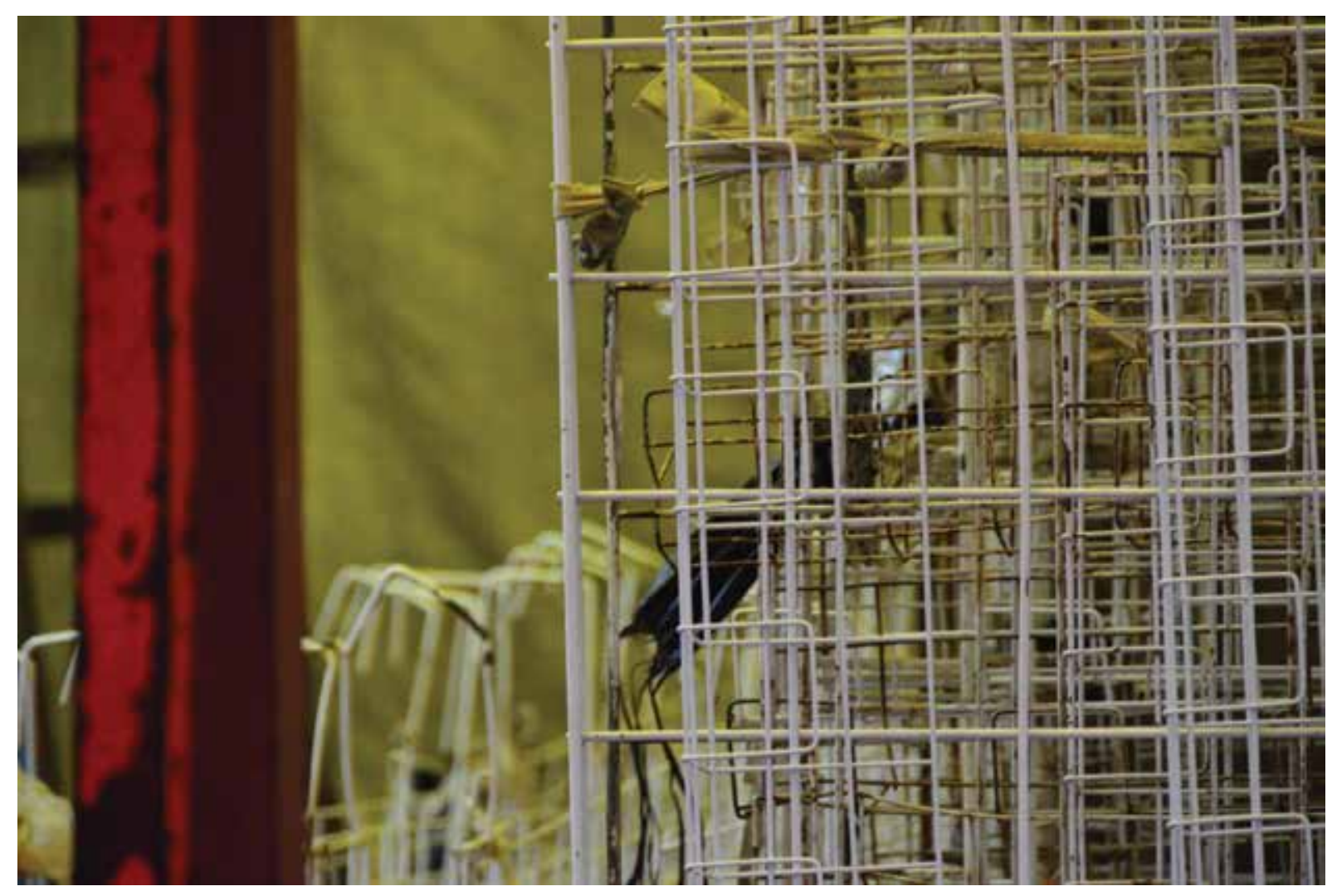




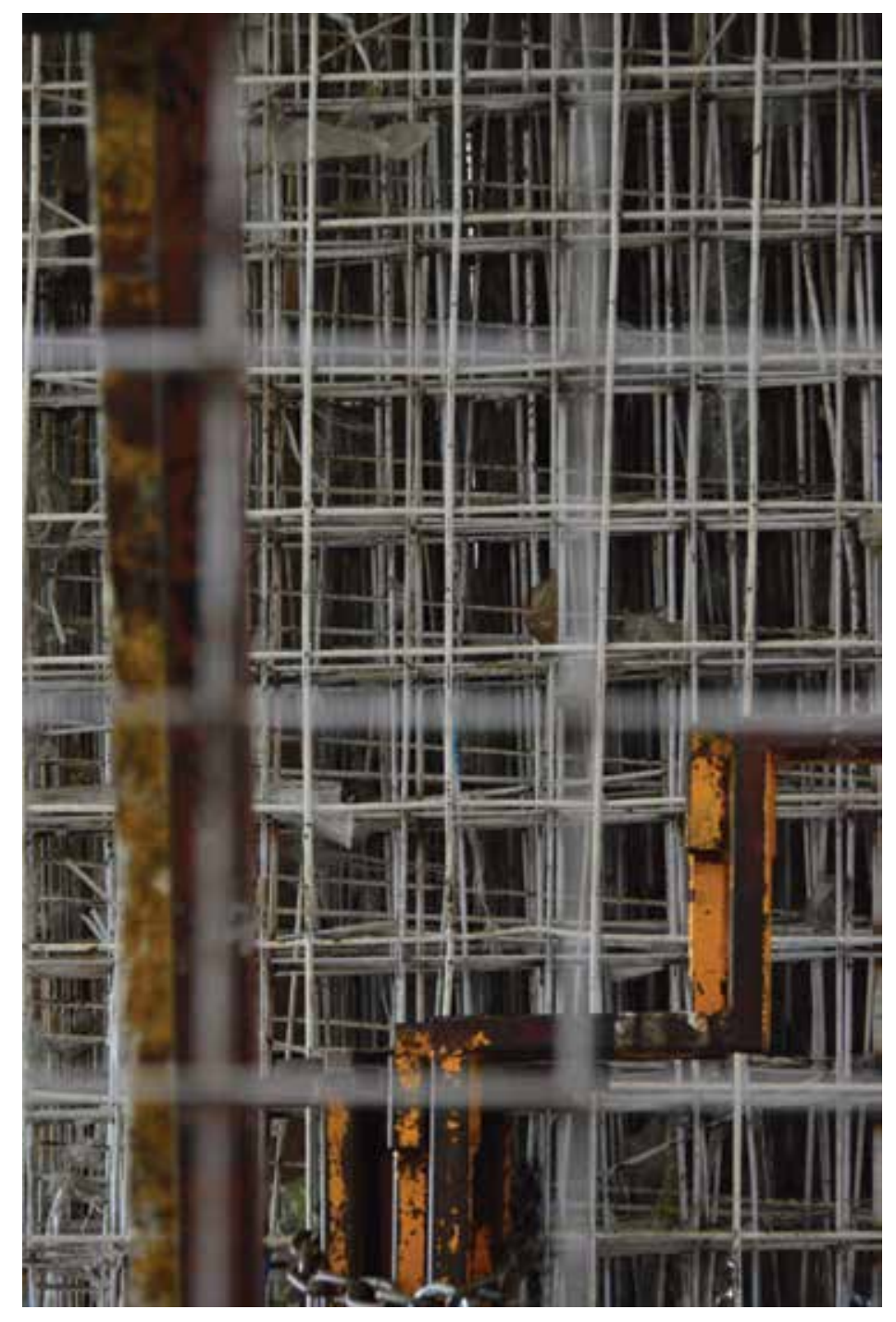




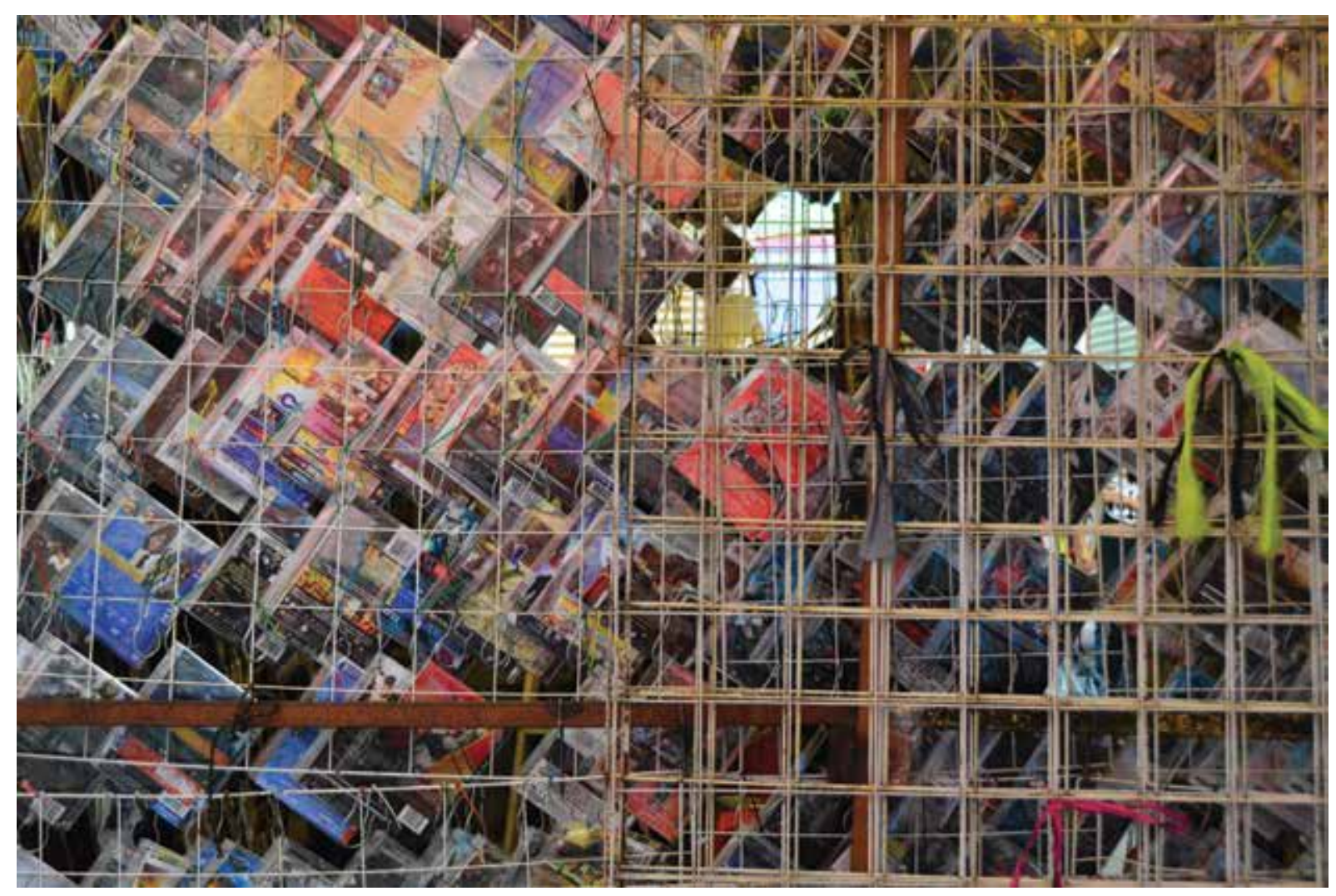




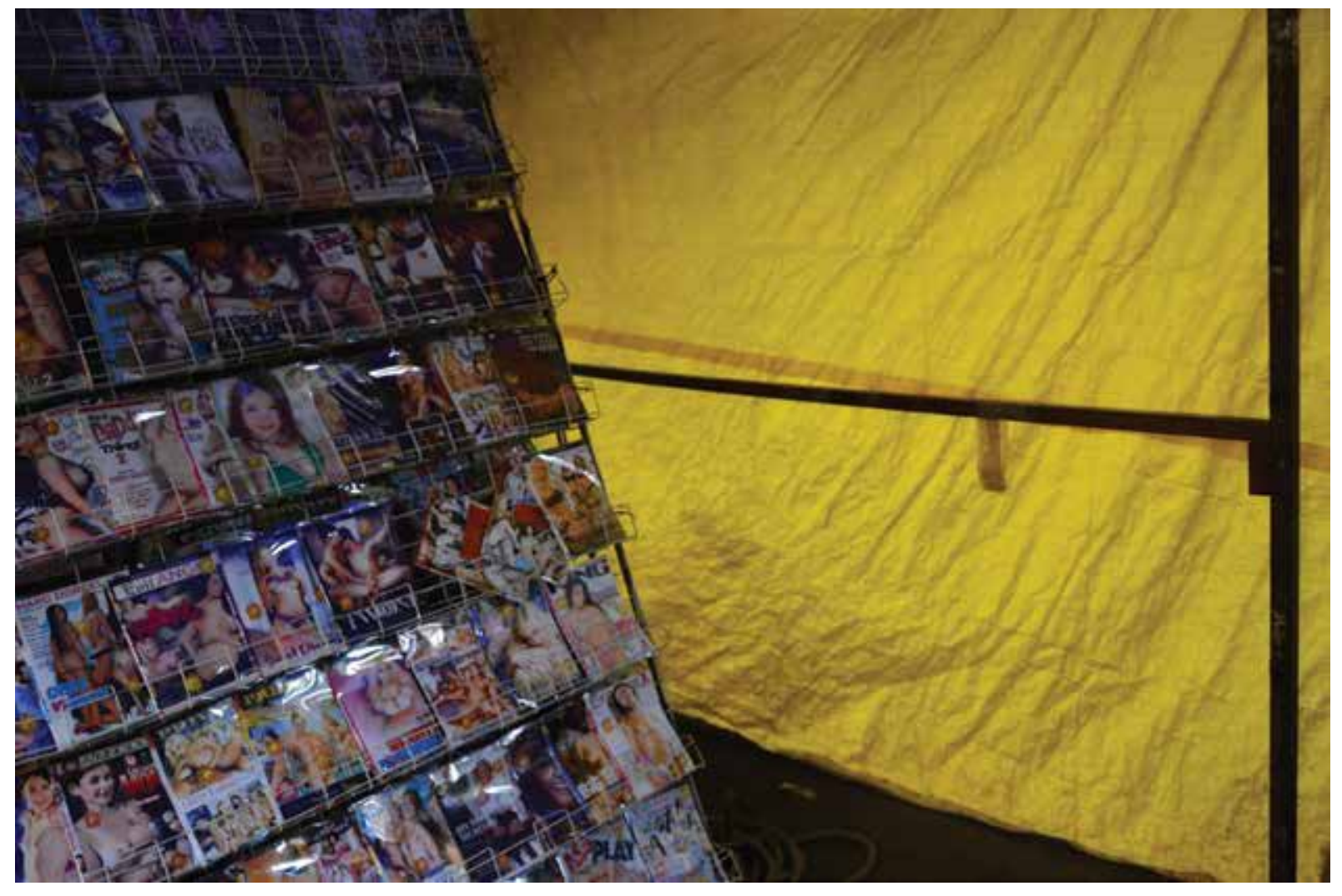




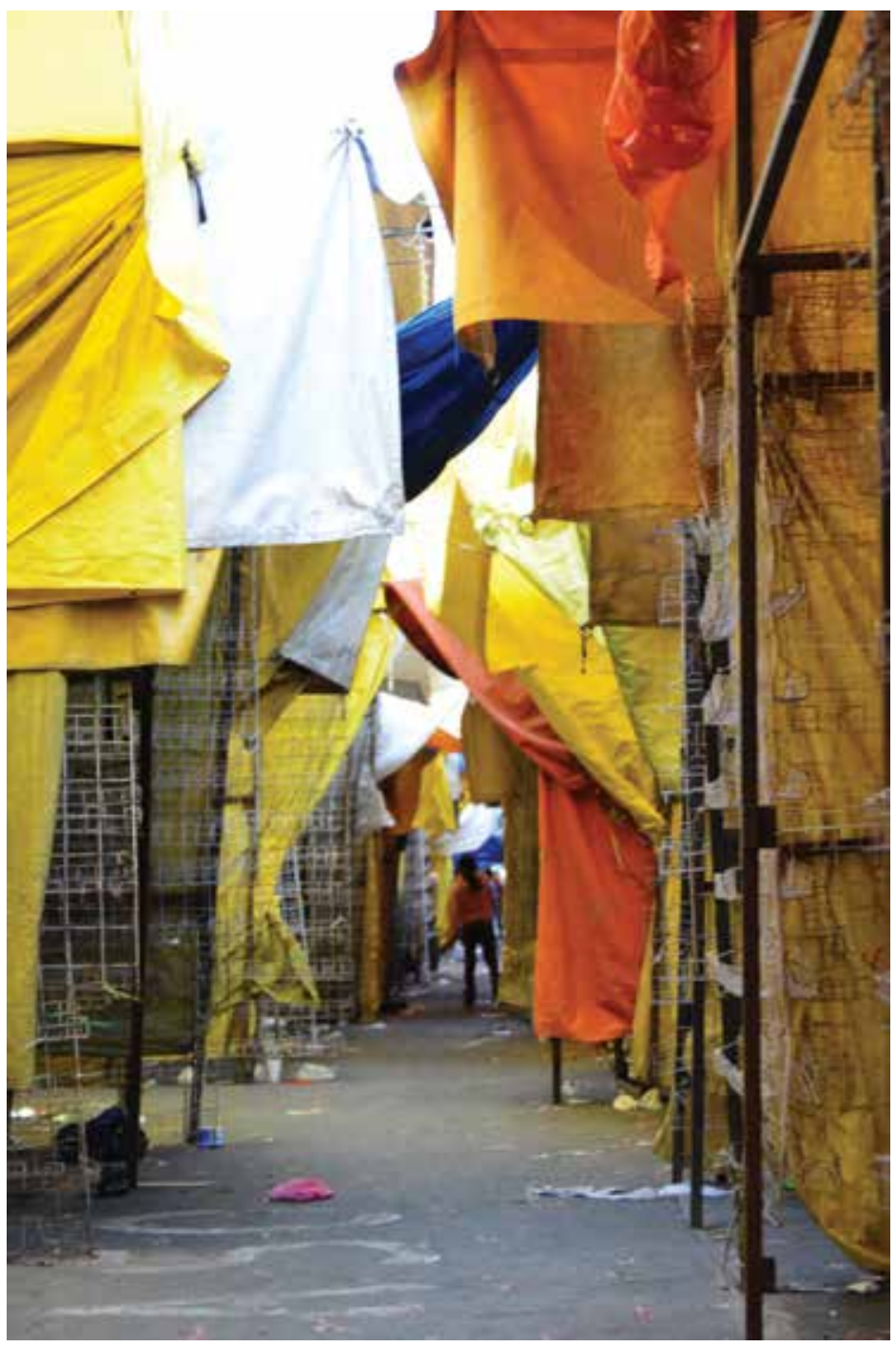

